\title{
Influence of nitrate concentration on pigment content in Chlorella pyrenoidosa
}

\author{
M. KRYWALSKA AND J. SKRZYPCZYK
}

Department of General Chemistry, Institute of Biology and Physiology, Silesian School of Medicine

(Received: April 15, 1977)

\begin{abstract}
Investigations on the qualitative and quantitative composition of pigments in the alga Chlorella pyrenoidosa cultured on mineral media with different nitrate content may give results serving to establish the optimal concentration of the nitrogen source in the medium. It was demonstrated that the interrelations between the particular pigments in 5 kinds of media containing $0,0.128,0.192,0.256$ and $0.384 \mathrm{~g} \mathrm{~N} / 1$, respectively, are most favourable in the medium threefold enriched in nitrates. This fact may be explained on the basis of the value of the coefficients:

$\frac{\text { chlorophyll } a}{\text { chlorophyll } b}=3.28 \quad$ and $\quad \frac{\text { chlorophyll } a+b}{\text { carotenoids }}=3.13$

The lack of a nitrogen source in the medium causes significant changes in the total pigment content and in the particular fractions. It was also found that under conditions of nitrogen deficit the astaxanthin content increases.
\end{abstract}

\section{INTRODUCTION}

Both the qualitative and quantitative composition of pigments in the cells of algae depends largely on the culture conditions. The pigment content is conditioned above all by the light intensity (B o g o r u d, 1962), and an important role is played in the process of pigment biosynthesis by the nitrogen source in the mineral medium ( $\mathrm{K}$ a nazawa et al., 1970a).

An inorganic source of nitrogen plays a significant role in the metabolism of carbon compounds, mainly in processes of photosynthetic 
carbon reduction leading to a cycle of tricarboxylic acids and nitrogen derivatives ( $\mathrm{K}$ a n a z a w a et al., 1970b).

On the other hand, nitrogen deficit in the mineral medium is responsible for a decrease of pigment content of the chlorophyll group and the appearance of secondary carotenoids ( $\mathrm{Kirk}$ and $\mathrm{Tilney-Bas-}$ s e t, 1967; O' K e ll e y, 1968; M a y e r and C z y g a n, 1969). Changes in the colour of the cells are frequently utilized as a taxonomic criterion. For instance, in cultures enriched in nitrogen, cells of algae are usually intensively green, whereas under conditions of nitrogen deficiency they are of a yellow-green colour (Mos s, 1974).

Algae of the genus Chlorella pyrenoidosa when cultured on mineral media with different nitrate content show varying intensities of pigmentation. On the basis of this observation it seemded interesting to compare the qualitative and quantitative composition of the pigments in these algae cultured on media with an increasing nitrate content and deprived of nitrogen source. Trials were also made to establish whether the medium used in the experiments as standard ensures an appropriate composition and interrelations of the pigments in the Chlorella pyrenoidosa cells.

\section{MATERIAL AND METHODS}

1. The object of investigations were algae of the genus Chlorella pyrenoidosa from the algological collection of the Institute of Zootechnics in Zator (B ednarz and Nowak, 1972). The algae were cultured on sterilized mineral medium according to L ef è v r e (1952) with a microelement solution added after Vladimirova and Semenenkov (1962). The chemical composition of the particular mineral media with different nitrate content and without nitrogen is given in Table 1 . The cultures were run for 30 days extensively in conical flasks containing $1 \mathrm{l}$. of medium. The cultures were kept under continuous fluorescent tube light ("Daylight" - Telam) of 3100 lux intensity. The cultures were kept at $20^{\circ} \mathrm{C} \pm 2^{\circ}$ and the cell suspension was stirred daily by shaking.

2. Analysis of material. After the end of culture the number of cells in $1 \mathrm{ml}$ was determined in a Därker chamber. Since the number of cells on media with different nitrate content was not the same, such culture volumes were taken for pigment extraction as to obtain a final cell number of $1-1.5 \times 10^{10}$.

The algal biomass was washed twice with distilled water and the cell suspension was centrifuged each time. Then the cells were homogenized and the pigments extracted into a mixture of petroleum benzin (fraction with b.p. $40-60^{\circ} \mathrm{C}$ ) and acetone (1:1) with $\mathrm{MgCO}_{3}$ added. 


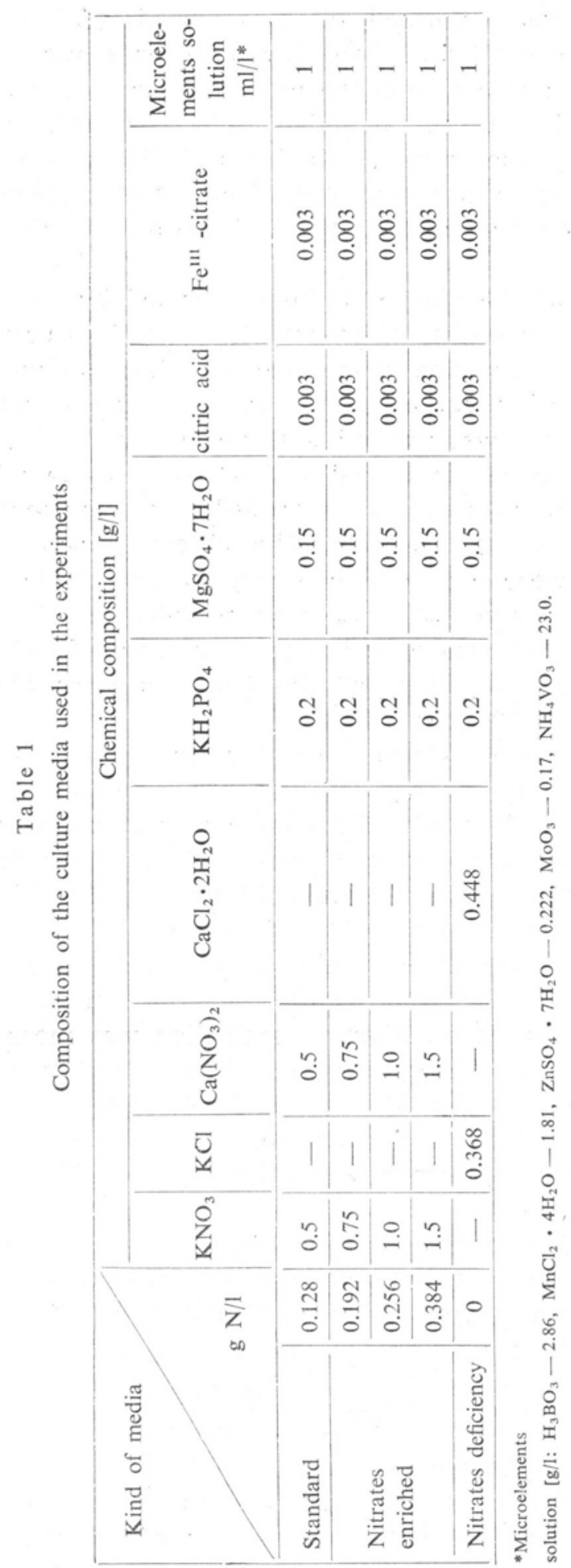


Homogenization was performed with glass beads $(\varnothing 0.15 \mathrm{~mm})$ in a vibration disintegrator (Micklie Lab., England) for $2 \mathrm{~min}$.

Acetone was removed from the extract by continuous washing with water (Opienska-B la u th and Trojanowski, 1967). Then, in order to dehydrate the extract, anhydrous $\mathrm{Na}_{2} \mathrm{SO}_{4}$ was added and after $30 \mathrm{~min}$ the mixture was centrifuged. The extract obtained was always made up with petroleum benzin to a volume of $10 \mathrm{~cm}^{3}$ and considered as outset extract.

Fractionation of the pigments was performed by column chromatography on activated starch (Goodwin, 1955; Tysarowski, 1968). Chromatographic separation was done in glass columns $(2 \times 20 \mathrm{~cm})$ filled to a height of $15 \mathrm{~cm}$ with previously prepared starch. The column filled with adsorbent was washed with petroleum benzin, and then the outset pigment extract was placed on it $(1 \mathrm{ml}$ of extract from standard cultures and from cultures with increased nitrate content and $2 \mathrm{ml}$ of culture without nitrogen source). The chromatogram was developed and carotenoids were eluted with a mixture of petroleum benzin and acetone (99:1) and the flow rate was adjusted to $15-20$ drops $/ \mathrm{min}$. Chlorophyll $a$ and $b$ was eluted with a mixture of petroleum benzin and acetone (95:5). Recovery of the fractions after chromatographic separation was $97-100$ per cent.

Acetone was removed from the particular pigment fractions by the method of continuous washing with water (Opien s k a-B la u th and Trojanowski, 1967) and the obtained fractions were dried with anhydrous $\mathrm{Na}_{2} \mathrm{SO}_{4}$. The particular carotenoid fractions were made up with petroleum benzin to a volume of $10 \mathrm{~cm}^{3}$ and the chlorophyll $a$ and $b$ fractions were made up to a $50 \mathrm{~cm}^{3}$ volume.

Absorption was measured in the outset extract and the separated pigment fractions within wavelength $400-700 \mathrm{~nm}$ (spectrophotometre VSU-2P, Carl Zeiss, Jena). Pigment extinction was measured in a cell with pathlength $1 \mathrm{~cm}$. Absorption was measured at $20 \mathrm{~nm}$ intervals, and in the wavelength ranges $420-460$ and $640-660$ at $2 \mathrm{~nm}$ intervals. Maximum extinction for the particular fractions in petroleum benzin solution shows good agreement with the data in table 2 (Goodwin, 1955).

From extinction measurements at a definite wavelength total extinction $\left(\mathrm{E}_{\mathrm{tot}}\right)$ of the outset extract and of the separated pigment fractions was calculated. The results were recalculated to $10^{6}$ algal cells. The calculation was done according to the formula

where: $\mathrm{E}_{\text {tot }}$ - total extinction

$$
\mathrm{E}_{\text {tot }}=\frac{10^{6} \times \mathrm{E}_{\mathrm{i}} \times \mathrm{V}_{\mathrm{i}}}{\mathrm{N} \times \mathrm{V}}
$$

$\mathrm{E}_{\mathrm{i}}$ - extinction measurement values

$\mathrm{V}_{\mathrm{i}}$ - volume of outset extract or of determined carotenoid 
fraction and chlorophylls

$\mathrm{V}$ - total volume

$\mathrm{N}$ - number of cells examined

$10^{6}$ - constant number of cells

The mean values of the data shown in the tables were calculated on the basis of 4 independent determinations.

Table 2

Maximum absorption of pigments in petroleum ether (Goodwin 1965)

\begin{tabular}{|l|c|}
\hline \multicolumn{1}{|c|}{ Pigment } & Wavelength [nm] \\
\hline B-carotene & 430 \\
lutein & 440 \\
Violaxanthin & 434 \\
Neoxanthin & 436 \\
Astaxanthin & 440 \\
Chlorophyll $a$ & 430,660 \\
Chlorophyll $b$ & 460,640 \\
\hline
\end{tabular}

\section{RESULTS AND DISCUSSION}

The results obtained point to a relation between the qualitative and quantitative composition of the pigments and the nitrogen salt level in the mineral medium. An increase of the nitrate content in the medium $(0.192 \mathrm{~g} \mathrm{~N} / \mathrm{l}$. and $0.256 \mathrm{~g} \mathrm{~N} / \mathrm{l}$ ) $)$ does not cause an increase in the total pigment content in the cells (Table 3 ). Neither were significant differences observed in the quantitative composition of the pigments in

Table 3

Pigment content in Chlorella cultivated in the media with different concentration of nitrogen and without nitrogen /mean value in $\mathrm{E}_{\mathrm{tot}} / 10^{6}$ cells

\begin{tabular}{|c|c|c|c|c|c|}
\hline \multirow{2}{*}{ Pigment fractions } & \multicolumn{5}{|c|}{ Concentration of nitrates in $\mathrm{g} \mathrm{N} / \mathrm{l}$} \\
\hline & 0.128 & 0.192 & 0.256 & 0.384 & 0 \\
\hline$\beta$-carotene & $0.28 \cdot 10^{-2}$ & $0.22 \cdot 10^{-2}$ & $0.22 \cdot 10^{-2}$ & $0.28 \cdot 10^{-2}$ & $0.13 \cdot 10^{-2}$ \\
\hline Lutein & $1.35 \cdot 10^{-2}$ & $1.58 \cdot 10^{-2}$ & $1.14 \cdot 10^{-2}$ & $1.31 \cdot 10^{-2}$ & $0.72 \cdot 10^{-2}$ \\
\hline Violaxanthin & $0.25 \cdot 10^{-2}$ & $0.26 \cdot 10^{-2}$ & $0.15 \cdot 10^{-2}$ & $0.22 \cdot 10^{-2}$ & $0.19 \cdot 10^{-2}$ \\
\hline Astaxanthin & - & 一 & - & 一 & $0.06 \cdot 10^{-2}$ \\
\hline Chlorophyll $a$ & $2.56 \cdot 10^{-2}$ & $2.26 \cdot 10^{-2}$ & $2.80 \cdot 10^{-2}$ & $5.23 \cdot 10^{-2}$ & $0.58 \cdot 10^{-2}$ \\
\hline Chlorophyll $b$ & $1.22 \cdot 10^{-2}$ & $1.00 \cdot 10^{-2}$ & $1.20 \cdot 10^{-2}$ & $1.60 \cdot 10^{-2}$ & $0.26 \cdot 10^{-2}$ \\
\hline Neoxanthin & $0.34 \cdot 10^{-2}$ & $0.28 \cdot 10^{-2}$ & $0.29 \cdot 10^{-2}$ & $0.36 \cdot 10^{-2}$ & $0.06 \cdot 10^{-2}$ \\
\hline $\begin{array}{l}\text { Total amount } \\
\text { of pigment }\end{array}$ & $6.00 \cdot 10^{-2}$ & $5.60 \cdot 10^{-2}$ & $5.80 \cdot 10^{-2}$ & $9.00 \cdot 10^{-2}$ & $2.00 \cdot 10^{-2}$ \\
\hline
\end{tabular}


cells cultured on medium containing $0.192 \mathrm{~g} \mathrm{~N} / 1$. A twofold increase in nitrate content as compared with that in the standard medium, causes, however, an increase in chlorophyll $a$ content with simultaneous depression of the carotenoid level, particularly violaxanthin (Table 4).

Table 4

Content of pigments in Chlorella cultivated in the media containing different concentration of nitrogen and without nitrogen (in \%)

\begin{tabular}{|l|r|r|r|r|r|}
\hline \multirow{2}{*}{ Pigment fractions } & \multicolumn{5}{|c|}{ Concentration of nitrates in $\mathrm{g} \mathrm{N} / 1$} \\
\cline { 2 - 5 } & 0.128 & 0.192 & 0.256 & 0.384 & 0 \\
\hline$\beta$-carotene & 4.7 & 3.9 & 3.8 & 3.2 & 6.5 \\
\hline Lutein & 22.5 & 28.2 & 19.7 & 14.5 & 36.0 \\
\hline Violaxanthin & 4.2 & 4.6 & 2.6 & 2.5 & 9.5 \\
\hline Astaxanthin & - & - & - & - & 3.0 \\
\hline Chlorophyll $a$ & 42.7 & 40.4 & 48.2 & 58.1 & 29.0 \\
\hline \begin{tabular}{l|l|l|l|} 
Chlorophyll $b$ \\
\hline Neoxanthin
\end{tabular} & 20.3 & 17.9 & 20.7 & 17.7 & 13.0 \\
\hline $\begin{array}{l}\text { Total amount } \\
\text { of pigment }\end{array}$ & 5.6 & 5.0 & 5.0 & 4.0 & 3.0 \\
\hline
\end{tabular}

Most conspicuous changes in the proportions of the pigments of the carotenoid group and chlorophyll $a$ and $b$ were noted, as shown in table 5 , in algae cultured on media containing a 3 -fold raised amount of nitrates $(0.384 \mathrm{~g} \mathrm{~N} / 1$.). In cells from these cultures a distinct decrease of carotenoid content was observed with simultaneous rise of the chlorophyll level, particularly chlorophyll $a$. It may be that such a concentration of nitrate enchances the ability of assimilation of larger nitrogen amounts from the medium by the algae. This nitrogen would be mainly utilized for more intensive synthesis of porphyrin pigments.

According to Goodwin (1965) synthesis of the chlorophylls occurs parallelly to that of carotenoids. Normal simultaneous increase in the content of both these fractions is, according to the above quoted data, a manifestation of chloroplast reproduction. This fact is confirmed by other investigations showing that the chlorophyll content in the cells of Chlorella is strictly associated with the stability of the lamellar system of the chloroplast ( $\mathrm{Zi}$ i g ler and $\mathrm{Sch}$ a n d er l, 1969). The chlorophyll level depends in turn on the enzymatic activity of chlorophyllase, although pigment formation or decomposition is also dependent on the simultaneously occurring synthesis and degradation of proteins and formation and degeneration of the chloroplast structure (B ö g e r, 1963; C hi b a et al., 1967).

It was demonstrated in the present experiments that during culture of algae disturbances occur in cell metabolism, owing to which the 
correlation between carotenoids and chlorophylls is impaired. The different nitrate content in the mineral medium is decisive for the level of the given pigment fraction in the plastides. During a 30-day culture of algae on a mineral medium with $0.384 \mathrm{~g} N / 1$. that is with a 3 times higher nitrate content than in the standard medium, only an enhanced chlorophyll $a$ synthesis occurs. This actually confirms the fact of increase of the chlorophyll $a$ to chlorophyll $b$ ratio, its value is 3.28 (Table 5).

Table 5

Coefficients of separate pigment fractions

\begin{tabular}{|c|c|c|c|c|c|}
\hline \multirow{2}{*}{ Coefficient } & \multicolumn{5}{|c|}{ Concentration of nitrates in $\mathrm{g} \mathrm{N} / \mathrm{l}$} \\
\hline & 0.128 & 0.192 & 0.256 & 0.384 & 0 \\
\hline Chlorophyll $a$ & & & & & \\
\hline Chlorophyll $b$ & 2.10 & 2.25 & 2.60 & 3.28 & 2.23 \\
\hline Chlorophyll $a$ & 15 & 006 & 155 & 240 & $0=50$ \\
\hline Carotenoids & 1.15 & 0.90 & 1.50 & 2.40 & 0.50 \\
\hline Chlorophyll $b$ & $0 \leq 4$ & 00 & & & \\
\hline Carotenoids & 0.24 & 0.42 & 0.66 & 0.13 & 0.22 \\
\hline Chlorophyll $a+b$ & 170 & 130 & 21 & 312 & 077 \\
\hline Carotenoids & 1.70 & 1.59 & 2.21 & 5.15 & 0.12 \\
\hline
\end{tabular}

In medium with 3 -fold higher nitrate content an increase is observed of the Chlorophyll $a+b$ to carotenoid ratio, which amounts to 3.13 . This coefficient is a resultant value of both the increased chlorophyll $a$ content and the lowered content of isoprenoid pigments in the cell. On the basis of numerical data from table 4 it may be calculated that in the culture with $0.384 \mathrm{~g} \mathrm{~N} / \mathrm{l}$. there is about 13 per cent more chlorophyll $a+b$ and about 15 per cent less carotenoids as compared with the same data for the standard culture $(0.128 \mathrm{~g} \cdot \mathrm{N} / \mathrm{l}$.).

In cultures of algae on medium with nitrogen source eliminated completely, opposite changes occur in the carotenoid and chlorophyll pigment content as compared with the media containing nitrates. In the nitrogen-free culture as little as 42 per cent of the total amount of pigments consists of chlorophyll $a+b$. The contribution of carotenoids, on the other hand, is very high amounting to 58 per cent. The reduction of the chlorophyll content with simultaneous increase in carotenoids in cells cultured without a nitrogen source is still more pronounced when an organic carbon source is present in the medium in the form of acetates or glucose ( $\mathrm{M}$ a t su k a et al., 1969a, b). These relations seem to be fully justified and in agreement with the processes of chlorophyll biosynthesis where $\delta$-aminolevulinic acid is the immediate precursor in the synthesis of the pyrole ring (Porra and Grimme, 1974). Nitro- 
gen deficit in the mineral medium probably causes a gradual inhibition of chlorophyll synthesis in the cell. This is also confirmed by the results of $\mathrm{Oc} \mathrm{hi}$ a i et al. (1970) from which it results that in cells cultured on nitrogen-free medium, the lipid content rises with specific inhibition of $\delta$-aminolevulinic acid synthesis. Noteworthy are also the observations concerning far advanced reduction of the chloroplast structure in cells cultured in medium without a nitrogen source ( $\mathrm{S} \mathrm{k} \mathrm{z} \mathrm{y} \mathrm{p} \mathrm{z} \mathrm{y} \mathrm{k,} \mathrm{1971).}$ Investigations on the diverse bonds between proteins and pigments suggest that the raised carotenoid level plays a role in the stabilization of thylakoid structures during nitrogen starvation (D e roche and Cos t e s, 1969).

In view of the results of experiments, the fact should be stressed that, in cells cultured under nitrogen-free conditions, the amount of pigments of the xanthophyll group, for instance lutein and violaxanthin, increased by 36 and 9.5 per cent, respectively. This can be explained by the fact that xanthophylls are photosynthetically active pigments, in contrast to carotenes which only play a protective role in respect to other chloroplastid pigments (B l a i m, 1967). The essential difference in the quantitative composition of the pigments of algae cultured on nitrogen-free medium is shown in the numerical data listed in table 5 . It results from these data that the value of the chlorophyll $a+b$ to carotenoid ratio is 0.72 , thus more than two times less as compared with that for cells from standard cultures. On the other hand, in cells of algae cultured on medium with a 3-times higher nitrate content, the ratio of these pigments reaches a value of 3.13 , that is about 4 times higher than in the case of nitrogen-free medium.

The most characteristic feature in the pigment relations of the alga Chlorella pyrenoidosa cultured on medium without a nitrogen source is the raised astaxanthin level, that is the ketone derivative of $\beta$-carotene. The results concerning formation of secondary carotenoids under conditions of nitrogen deficit are in agreement with those obtained in the investigations of Ders ch (1960), C z y g a n $(1964,1968 \mathrm{a}, \mathrm{b})$ and $\mathrm{K}$ o ssler (1963). The presence of astaxanthin both in Chlorophyceae and Euglenopiryceae is a taxonomic criterion on the one hand, and on the other, it indicates the line of phylogenetic development of these organisms (H i r o s e, 1975).

The values of the particular coefficients presented in table 5 for the pigments from Chlorella pyrenoidosa cells are largely conformable with analogous coefficients for other algae (W e b e r, 1969) and higher plants ( $M$ üntz, 1966). It was demonstrated in the present experiments that the composition of pigments in Chlorella pyrenoidosa cells is normal when the culture medium contains $0.384 \mathrm{~g} \mathrm{~N} / \mathrm{l}$, that is when it is enriched 3 -fold in nitrates as compared with the standard medium used to date.

The chlorophyll $a$ to $b$ ratio which for Chlorella pyrenoidosa is 3.28 
is very close to the result obtained by $\mathrm{P}$ orr a and Grimme (1974) for Chlorella fusca. For cells of the same species cultured on medium without nitrogen source, the chlorophyll $a$ to $b$ ratio is 2.3 . In the here presented experiment the same ratio for Chlorella pyrenoidosa cells is 2.23 .

Comparison of the results of analysis of pigments from algae cultured on media with different nitrate content may serve as criterion for establishing the optimal chemical conditions for their culture.

\section{REFERENCES}

Bednarz T. and Nowak M., 1972. The selection of algae for mass culture purposes. Acta Hydrobiol. 14 (1): 1-18.

B l a i m K., 1967. Barwniki roślinne, PWRiL, Warszawa, pp. 130-185.

B o g o r a d L., 1962. Chlorophylls, [In:] R. A. Lewin, ed., Physiology and Biochemistry of Algae, Academic Press New York and London, pp. 385-404.

Böger R., 1965. Chlorophyllase of Chlorella vulgaris Beijerinck. Phytochemistry 4: $435-443$.

Chiba Y., Aiga I., Idemori M., Satoh Y., Matsushita K. and Sas a T., 1967. Studies on chlorophyllase of Chlorella protothecoides. I. Enzymatic phytylation of methyl chlorophyllide. Plant Cell Physiol. 8: 623-635.

Czygan F. C., 1964. Untersuchungen über die Wirkung von Chloramphenicol auf den Auf- und Abbau der Pigmente einiger Grünalgen. Arch. Mikrobiol. 47: 251-258.

C z y g a n F. C., 1968a. Sekundär-Carotinoide in Grünalgen. I. Chemie, Vorkommen und Faktoren, welche die Bildung dieser Polyene beeinflussen. Arch. Mikrobiol. 61: 81-102.

C z y g a n F. C., 1968b. Sekundär-Carotinoide in Grünalgen. II. Untersuchungen zur Biogenese. Arch. Mikrobiol. 62: 209-236.

Deroche M. E. and Costes C., 1969. Heterogeneity of carotenoids in chloroplasts. Progress in Photosynthesis Research. Vol. 2: 681-693.

Dersch G., 1960. Mineralsalzmangel und Sekundärcarotinoide in Grünalgen. Flora. 149: 566-603.

Goodwin T. W., 1955. Carotenoids, [In:] K. Peach and M. W. Tracey, ed., III. Moderne Methoden der Pflanzenanalyse. Springer Verlag, Berlin-Göttingen -Heidelberg, pp. 272-311.

G o o d w in T. W., 1965. The biosynthesis of carotenoids [In:] T. W. Goodwin, ed., Chemistry and Biochemistry of Plant Pigments, Academic Press, London and New York, pp. 143-173.

Hirose H., 1975. Photoreactive pigments of algae and algal phylogeny. [In:] J. Tokida and H. Hirose, ed., Advance of Physiology in Japan, VEB Gustav Fischer Verlag, Jena, pp. 52-65.

Kan azawa T., Kanazawa K., Kirk M. R. and Bas sham J. A., 1970a. Differences in nitrate reduction in "light" and "dark" stages of synchronously growing Chlorella pyrenoidosa and resultatant metabolic changes. Pl. Cell. Physiol., Tokyo. 11: 445-452.

K a nazawa T., Kirk M. R. and Bassham J. A., 1970b. Regulatory effects of ammonia on carbon metabolism in photosynthesising Chlorella pyrenoidosa. Biochim. Biophys. Acta 205: 401-408.

Kessler E., Langner W., Ludewig I. und Wiechmann H., 1963. Bild- 
ung von Sekundär-Carotenoiden bei Stickstoffmangel und Hydrogenase-Aktivität als taxonomische Merkmale in der Gattung Chlorella, [In:] Studies on Microalgae and Photosynthetic Bacteria, Japanese Soc. of Plant Physiologists; Tokyo, pp. 7-20.

Kirk J. T. O. and Tilney-Basset R. A. E., 1967. The Plastids: their chemistry, structure, growth and inheritance, W. H. Freeman and Co.; London.

L e f èv $\mathrm{r}$ e M., J a c o b $\mathrm{H}$. et $\mathrm{N}$ i s.bet. M., 1952. Auto- et hétéroantagonisme chez les algues d'eau douce in vitro et dans les collections d'eau naturelles. Ann. sta. centre hydrobiol. appl. 4: 5-19.

Matsuka'M., Miyachi S. and Hase E., 1969a. Further studies on metabolism of glucose in the process of glucose bleaching of Chlorella protothecoides. Pl. Cell Physiol., Tokyo, 10: 503-512.

Matsuka M., Miyachi S. and $\mathrm{Hase}$ E., 1969b. Acetate metabolism in the process of "acetate bleaching" of Chlorella protothecoides. Pl. Cell. Physiol., Tokyo, 10: 513-526.

M a y er F. und $\mathrm{Czy}$ g a $\mathrm{n}$ F.-C., 1969. Änderungen der Ultrastrukturen in den Grünalgen Ankistrodesmus braunii und Chlorella fusca var. rubescens bei Stickstoffmangel. Planta (Berl.) 86: 175-185.

M üntz K., 1966. Stoffwechsel der Pflanzen, Volk und Wissen, Volkseigener Verlag, Berlin, pp. 252-254.

Mos s B., 1974. Morphogenesis. [In:] W. D. P. Steward, ed., Algal Physiology and Biochemistry, Blackwell Scientific Publication, Oxford, London, Edinburgh, Melbourne, pp. 788-813.

$\mathrm{Ochiai}$ S. and Hase E., 1970. Studies on the chlorophyll formation in Chlorella protothecoides. I. Enhancing effects of light and added $\delta$-aminolevulinic acid and suppresive effect of glucose on chlorophyll formation. Pl. Cell. Physiol., Tokyo. 11: 663-673.

O'Kelle y J. C., 1968. Mineral nutrition of algae. Ann. Rev. Plant Physiol. 19: $89-112$.

Opieńska-Bla uth J., Trojanowski J., 1967. Zastosowanie chromatografii w fitochemii, PWRiL, Warszawa.

Porra R. J. and Grimme L. H., 1974. Chlorophyll synthesis and intracellular fluctuations of 5-aminolaevulinate formation during the regreening of nitrogen - deficient Chlorella fusca. Arch. Biochem. Biophys. 164: 312-323.

Skrzypczyk J., 1971. Biochemiczne kryteria wzrostu glonów.(ms).

Tysarowski W., 1968. Biochemia praktyczna, PWRiL, Warszawa.

Vla dimirova M. G. i Semenenko V. E., 1962. Intensivnaya kultura odnokletokhnych vodoroslei, Akad. Nauk SSSR, Moskva.

W e ber A., 1969. Uber die Chloroplastenfarbstoffe einiger Conjugaten. Flora, Abt. A, Bd. 160: 457-473.

$\mathrm{Z}$ i e gler.R. and $\mathrm{Sch}$ anderl S. H., 1969. Some aspects of the degradation of chlorophyll in a mutant of Chlorella. Progress in Photosynthesis Research 2: 635-645.

Author's address:

Dr Monika Krywalska and Dr Józef Skrzypczyk

Department of General Chemistry,

Institute of Biology and Physiology,

Silesian School of Medicine;

41-808 Zabrze - Rokitnica, Poland 
Wpływ różnych stężeń soli azotowych $w$ pożywce mineralnej na zawartość pigmentów $w$ glonach Chlorella, szczep 366.

\section{Streszczenie}

Badania składu jakościowego i ilościowego barwników w glonach Chlorella, szczep 366, hodowanych na pożywkach mineralnych o zróżnicowanej zawartośc1 azotanów mogą służyć jako kryterium dla ustalenia optymalnego stężenia źródła azotu w pożywce. Spośród 5 rodzajów pożywek, zawierających odpowiednio 0 , $100,150,200$ i $300 \% \mathrm{~N}$, wzajemne stosunki poszczególnych barwników kształtują się najkorzystniej $\mathrm{w}$ pożywce wzbogaconej 3 -krotnie $\mathrm{w} \mathrm{KNO}_{3}$. Fakt ten można uzasadnić w oparciu o wartości liczbowe odpowiednich współczynników:

$$
\begin{aligned}
& \frac{\text { chlorofil } a}{\text { chlorofil } b}=3,28 \text { oraz } \\
& \frac{\text { chlorofil } a+b}{\text { karotenoidy }}=3,13
\end{aligned}
$$

Brak zródła azotu w pożywkach wywołuje istotne zmiany w poziomie całkowitym barwników oraz $\mathrm{w}$ poszczególnych frakcjach. Ponadto stwierdzono, że w warunkach deficytu azotowego dochodzi do pojawienia się astaksantyny. 